\title{
MODUS TINDAK TUTUR REPRESENTATIF PADA CERAMAH USTAZ MAULANA “ACARA ISLAM ITU INDAH”
}

\author{
Izah Azizah Zaen ${ }^{1}$, Zainal Rafli ${ }^{2}$, Miftahul Khairah ${ }^{3}$ \\ Program Magister Pendidikan Bahasa, Universitas Negeri Jakarta \\ Iizahazizah98@gmail.com
}

\begin{abstract}
Abstrak
Tindak Tutur Representatif dalam acara Islam Itu Indah pada Ceramah Ustaz Muhammad Nur Maulana, Suatu Kajian Pragmatik. Masalah yang dibahas dalam penelitian ini adalah mendeskripsikan modus yang melatarbelakangi penggunaan tindak tutur representatif dalam cermah Ustaz Muhammad Nur Maulana. Jenis penelitian ini bersifat deskriptif kualitatif. Sumber data dalam penelitian ini adalah video ceramah Ustaz Muhammad Nur Maulana dari youtube. Data dalam penelitian ini berupa data tulis yaitu transkrip tuturan dari video ceramah Ustaz Muhammad Nur Maulana yang mengindikasikan sebagai modus tindak tuturnya. Metode pengumpulan data dengan menggunakan metode simak dengan teknik dasar sadap dan teknik lanjutan Simak Bebas Libat Cakap (SBLC) dan Catat. Metode Analisis data dalam penelitian ini menggunakan metode padan. Selanjutnya hasil analisis data disajikan dengan menggunakan metode informal Berdasarkan analisis data, dalam penelitian ini dapat disimpulkan dalam ceramah Ustaz Muhammad Nur Maulana terdapat enam modus jenis tindak tutur, yaitu modus indikatif, modus imperatif, interogatif, obligatif, desideratif dan kondisional.
\end{abstract}

Kata Kunci: Modus Tindak Tutur Representatif, Cerama

\begin{abstract}
The follow-up of representatives at the event Islam Itu Indah at Ustaz Muhammad Nur Maulana's lecture, a pragmatic study. The problem discussed in this research is describing the mode which is the background of the use of the said Representative in the discourse Ustaz Muhammad Nur Maulana. This type of research is qualitative descriptive. The source of the data in this study is a video of Ustaz Muhammad Nur Maulana's lecture from YouTube. The data in this study in the form of writing data, i.e. the speech transcript from a video lecture of Ustaz Muhammad Nur Maulana indicating the mode of follow-up. Data collection method using the method of check with the basic technique of SADAP and advanced techniques See Libat Proficient (SBLC) and note. The data analysis method in this study uses the method of fit. Further data analysis results are presented using informal methods based on data analysis, in this study can be concluded in the talks Ustaz Muhammad Nur Maulana There are six modes of the type of action, namely indicative mode, mode Imperative, interrogative, obligative, desideratif and conditional.
\end{abstract}

Keywords: A representative mode of action, Ustaz

\section{PENDAHULUAN}

Penggunaan bahasa yang terjadi dalam ceramah Ustaz Muhammad Nur Maulana pada acara 'Islam Itu Indah' dapat dikaji dalam ilmu pragmatik khususnya dalam tindak tutur representatif. Tindak tutur representatif melibatkan penutur pada kebenaran proposisi yang diungkapkannya. Tuturan dalam ceramah Ustaz Maulana mengindikasikan tindak 
tutur representatif. Hal ini karena dalam menyampaikan sebuah tuturan baik berupa informasi, saran, penjelasan, pendapat, ide, pernyataan, maupun perasaan kepada khalayak umum seorang pembicara harus bertutur dengan benar dan apa yang dituturkan dapat dipertanggungjawabkan kebenarannya, sehingga penutur tidak hanya sekadar berbicara, namun apa yang disampaikannya memiliki dasar pemikiran yang dapat dibuktikan kebenarannya oleh pendengar atau mitra tutur.

Salah satu tuturan yang menarik untuk dikaji secara pragmatik adalah tuturan yang disampaikan dalam ceramah, karena Ustaz Maulana memiliki perbedaan dengan penceramah lainnya, si pengisi acara kondang dengan nama lengkap Muhammad Nur Maulana, biasa akrab dipanggil Ustaz Maulana, merupakan dai "gaul", dan juga dapat dikatakan unik, jenaka, dan murah senyum. Keunikan yang ada pada Ustaz Maulana terletak pada cara penyampaian dalam ceramahnya dan cara menyapa jamaahnya. Sapaan "jamaah oh jamaah" dengan dialek, intonasi dan gerakan yang khas selalu disebutkannya saat berceramah. Sapaan tersebut menjadikan suasana santai dan tidak monoton. Cara Ustaz Maulana berdakwah tersebut menjadikan sebuah daya tarik tersendiri.

Pemilihan tema dan materi yang disampaikan selalu berkaitan dengan realita yang terjadi di dalam kehidupan masyarakat. Pembawaan ceramah seperti itulah membuat pendengar lebih mudah menangkap materi yang disampaikan oleh Ustaz Maulana. Selain mengundang tawa para pendengarnya, juga dapat menarik banyak penggemar pada acara dakwah tersebut.

Acara "Islam Itu Indah" merupakan kemasan Talk Show dakwah yang berbeda. Hadir setiap pagi di Trans TV memperoleh rating yang cukup bagus dengan share 22 tertinggi untuk acara dakwah sejenisnya dalam tahun terahir ini.

Manusia ketika berbicara dengan orang lain memiliki kecenderungan untuk menyesuaikan teknik penggambaran pikiran dan perasaannya dengan tuturan yang akan disampaikan kepada mitra tuturnya, lebih utama bagi seorang penceramah. Hal tersebut bertujuan agar pendengar dapat memahami dengan baik tuturan yang diungkapkan oleh pembicara. Penggambaran suasana psikologis perbuatan menurut tafsiran pembicara tentang apa yang diucapkan disebut modus tutur.

Berdasarkan pemaparan di atas, rumusan masalah dalam penelitian ini adalah bagaimanakah modus tindak tutur representatif dalam ceramah Ustaz Muhammad Nur Maulana pada acara 'Islam Itu Indah'. Data yang dicantumkan adalah data yang berbentuk data asli dari tuturan yang terdapat dalam ceramah "Islam Itu Indah".

\section{METODE PENELITIAN}

Rancangan kualitatif digunakan sebagai penelitian. Menurut Strauss (2007:4) Penelitian kualitatif adalah penelitian yang temuannya tidak diperoleh melalui prosedur statistik dan bentuk hitungan lainnya, tetapi berupa prosedur yang menghasilkan data deskripsi berupa kata-kata tertulis atau secara lisan dari prilaku yang diamati". Bog dan Taylor (dalam Moleong, 1996: 3) berpendapat bahwa "Penelitian kualitatif adalah penelitian yang menghasilkan data deskripsi berupa kata-kata atau lisan dari orang-orang dan perilaku yang diamati". Jenis penelitian yang digunakan adalah deskriptif. "Penelitian deskriptif ditujukan untuk mendeskripsikan suatu keadaan atau fenomena-fenomena apa adanya" (Sukmadinata, 2010:18).

Data penelitian ini adalah segmen tutur(an) dan konteksnya, yang diindikasikan sebagai tindak tutur representatif beserta modus tutur dan strategi tindak tutur, yang dituturkan oleh Ustaz Maulana dalam ceramahnya. Sumber data dalam penelitian ini berupa video rekaman ceramah atau tuturan Ustaz Maulana yang didapat dari internet 
dengan laman https://www.youtube.com/results?search_query=islam+itu+indah+trans $+t v+$ tadi + pagi + tema + sabar $\% 2 C+i k h l a s \% 2 C+$ modal + untuk + Istiqomah yang diunduh pada tanggal 30 November 2018.

Teknik yang digunakan untuk pengumpulan data dalam penelitian ini adalah (1) teknik simak, teknik ini dilakukan untuk memperoleh data berupa segmen tutur (an) dan konteknya dengan menyimak ceramah Ustaz Maulana sampai selesai; (2) teknik catat atau transkripsi adalah memindahkan data yang semula berwujud data lisan menjadi data yang berwujud tertulis.

Teknik analisis data dalam penelitian ini adalah analisis data deskriptif kualitatif, karena data yang dihasilkan berupa data deskriptif yang diperoleh dari hasil pengamatan dari ceramah Ustaz Muhammad Nur Maulana. Langkah-langkah analisis data dalam penelitian ini sebagai berikut. 1) seleksi data adalah data yang termasuk dalam tindak tutur representatif dimasukkan dalam tabel pengumpul data dilengkapi dengan konteksnya; 2) pemeriksaan keabsahan data adalah data yang telah diseleksi berdasarkan tindak tutur representatif diperiksa keabsahannya dengan melihat buku dan literatur yang ada; 3) pengklasifikasian data adalah data yang telah diseleksi dan diperiksa keabsahannya diklasifikasikan berdasarkan jenis, modus tindak tutur; 4) pengodean data adalah pemberian kode yang dilakukan untuk mempermudah peneliti dalam menjabarkan hasil penelitian; 5) pendeskripsian data adalah data yang telah diklasifikasikan sesuai dengan jenis, modus dan strategi dideskripsikan sesuai dengan maksud penutur dengan melihat konteks; (6) Penyimpulan hasil akhir data adalah data yang telah diklasifikasikan dan dideskripsikan kemudian ditarik kesimpulan dari data yang telah dipaparkan.

\section{HASIL DAN PEMBAHASAN}

1. Hasil penelitan menunjukkan bahwa jenis tindak tutur representatif yang digunakan oleh Ustaz Muhammad Nur Maulana adalah :

Tabel 1 Hasil Temuan Jenis Tindak Tutur

Jenis Tindak Tutur

a) Tindak tutur representatif menjelaskan

\section{Konteks}

Data Tuturan

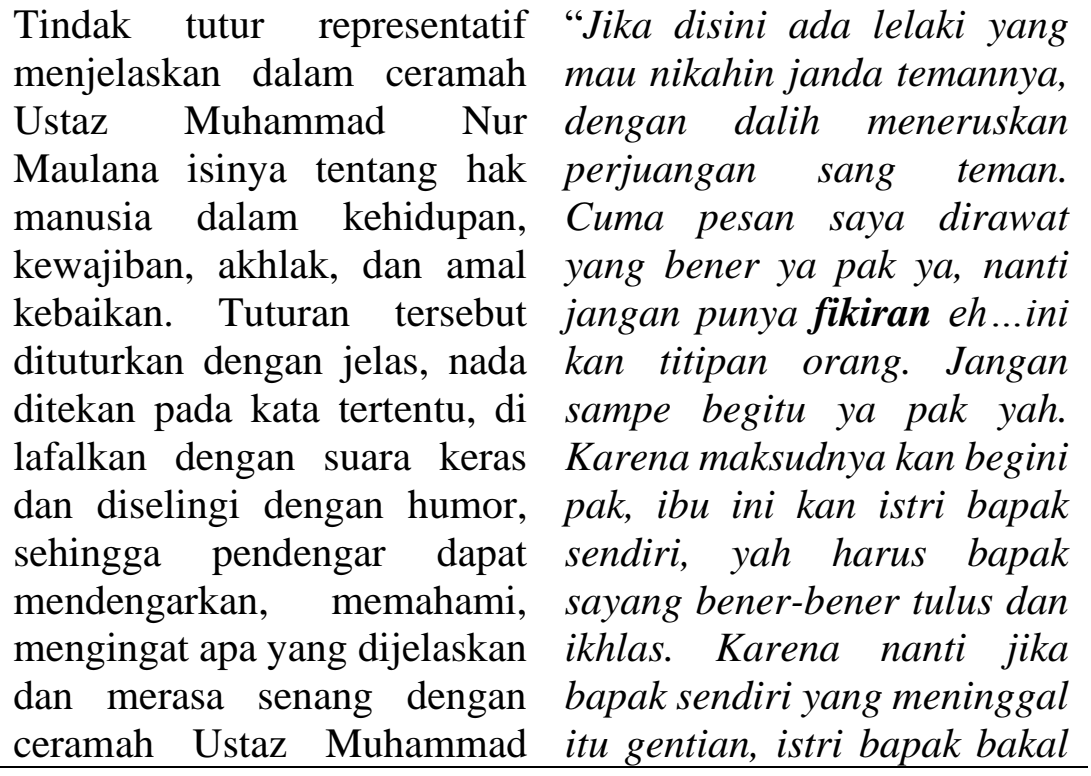




Nur Maulana. Penggunaan sayang dan cinta sama orang
tindak tutur representatif lain”. (TRMj: 1)
menjelaskan dalam ceramah
Ustaz Muhammad Nur
Maulanadapat terlihat pada
data berikut.

Tuturan tersebut disampaikan pada acara 'Islam Itu Indah' yang dilaksanakan setiap pagi di Studio TransTV. Tuturan disampaikan secara lisan oleh pembicara kepada pendengar dengan suara keras, nada rendah dan jelas, ekspresi sambil tersenyum penonton atau pendengar tertawa mendengarkan tuturan tersebut.

Tuturan yang disampaikan oleh penutur termasuk dalam tindak tutur representatif menjelaskan sebab dalam tuturan tersebut penutur berusaha menjelaskan kepada mitra tutur bahwa apa yang dimiliki oleh manusia saat ini suatu saat nanti akan dimiliki atau digantikan oleh orang lain. Dalam tuturan menjelaskan tersebut terdapat verba pemarkah penanda menjelaskan berupa bentuk kalimat "maksudnya kan begini". Frase tersebut dituturkan untuk memperjelas tuturan yang telah disampaikan oleh penutur.

Penanda frase menjelaskan dalam ceramah Ustaz Muhammad Nur Maulana ditandai dengan kalimat"maksudnya kan begini"yang merupakan bahasa Indonesia dengan ragam santai.

Tindak tutur representatif disampaikan dengan jelas, dengan suara keras dan ekspresi tersenyum. Penyampaian tuturan dengan cara seperti itu bermaksud untuk mempertegas penjelasan penutur, sehingga pendengar memahami penjelasan yang disampaikan oleh penutur tentang kesamaan hak yang dimiliki oleh manusia bahwa setiap manusia memiliki hak yang sama untuk mencintai dan memiliki. Ekspresi tersenyum yang ditunjukkan oleh penutur kepada pendengar membuat pendengar tidak merasa tersinggung dengan tuturan yang disampaikan oleh penutur.

Tabel 2 Hasil Temuan Jenis Tindak Tutur

\begin{tabular}{lll}
\hline Jenis Tindak Tutur & Konteks & Data Tuturan
\end{tabular}

b) Tindak tutur representatif menyatakan
Tindak tutur representatif menyatakan isinya tentang kekuasaan Tuhan dan akhlak manusia yang disampaikan dengan tegas, nada ditekan pada kata tertentu, dan dituturkan dengan suara keras, sehingga pendengar dapat mempercayai dan memahami pernyataan yang disampaikan penutur.

"Maka dari itu setiap bayi yang baru lahir pasti tangannya mengepal, ini adalah lambang dari Allah yang mahakuasa. Manusia itu maunya menggenggam dunia dan seisinya semaunya sendiri karena ingin menguasai (TRYt: 2)

Tuturan yang disampaikan penutur termasuk dalam tindak tutur representatif menyatakan sebab dalam tuturan tersebut penutur bermaksud menyampaikan pernyataan 
mengenai lambang yang diberikan oleh Allah kepada setiap bayi yang baru lahir. Dalam tuturan tersebut terdapat verba pemarkah penanda pernyataan berupa bentuk kata "pasti". Tuturan tersebut disampaikan dengan tegas, nada ditekan pada kata tertentu dan dituturkan dengan suara keras. Penyampaian tuturan dengan cara seperti itu dimaksudkan untuk memperjelas pernyataan yang dituturkan, sehingga pendengar memercayai dan memahami bahwa sejak lahir Tuhan sudah menggariskan sifat buruk yang dimiliki oleh semua manusia. Penuturan dengan suara keras dilakukan untuk meminta pendengar menyimak pernyataan yang diungkapkan karena pernyataan tersebut sangat penting untuk diketahui oleh pendengar.

Tabel 3 Hasil Temuan Jenis Tindak Tutur

\begin{tabular}{|c|c|c|}
\hline Jenis Tindak Tutur & Konteks & Data Tuturan \\
\hline 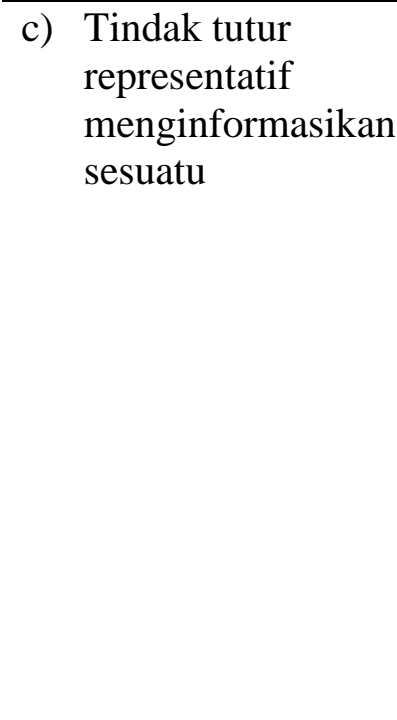 & $\begin{array}{l}\text { Tindak tutur representatif } \\
\text { menginformasikan sesuatu } \\
\text { berisi tentang penghargaan } \\
\text { yang diberikan oleh Tuhan } \\
\text { kepada manusia, yang } \\
\text { dituturkan dengan tegas, } \\
\text { suara keras dan diselingi } \\
\text { dengan humor, sehingga } \\
\text { pendengar memahami dan } \\
\text { menangkap dengan baik } \\
\text { informasi yang disampaikan } \\
\text { penutur serta merasa senang } \\
\text { dengan ceramah yang } \\
\text { disampaikan oleh Ustaz } \\
\text { Muhammad Nur Maulana. }\end{array}$ & $\begin{array}{l}\text { "Seperti halnya pada } \\
\text { pengajian atau taklim } \\
\text { mutak'lim ada keterangan } \\
\text { orang itu sudah ahli ilmu, } \\
\text { sudah mengaji beribu-ribu, } \\
\text { ngajinya sama dengan } \\
\text { atinya suka sama dengerin } \\
\text { ketika pertama ketika } \\
\text { dititipkan ilmu yang } \\
\text { bermanfaat sama Allah } \\
\text { Taala". (TRIn: } 3)\end{array}$ \\
\hline
\end{tabular}

Tuturan yang disampaikan oleh penutur termasuk tindak tutur representatif menginformasikan sesuatu sebab penutur bermaksud untuk menginformasikan kepada pendengar bahwa dalam sebuah kitab terdapat sebuah keterangan yang perlu diketahui oleh pendengar. Dalam tuturan menginformasikan sesuatu tersebut terdapat verba pemarkah dalam bentuk kalimat "Seperti halnya pada pengajian atau taklim mutaklim ada keterangan". Tuturan disampaikan dengan tegas, dengan suara keras, sehingga pendengar dapat memahami dan menangkap dengan baik informasi tentang seseorang yang ahli ilmu suatu saat nanti akan dilipat gandakan ilmunya. Penyampaian dengan suara keras dan diselingi dengan humor, sehingga pendengar dapat mengingatnya dengan baik dan merasa senang dengan tuturan yang disampaikan oleh Ustaz Muhammad Nur Maulana.

Tabel 4 Hasil Temuan Jenis Tindak Tutur

\begin{tabular}{|c|c|c|}
\hline Jenis Tindak Tutur & Konteks & Data Tuturan \\
\hline $\begin{array}{l}\text { d) tindak tutur } \\
\text { representatif } \\
\text { membanggakan }\end{array}$ & $\begin{array}{l}\text { Tuturan yang disampaikan } \\
\text { oleh penutur termasuk dalam } \\
\text { tindak tutur representatif }\end{array}$ & $\begin{array}{llr}\text { "Anda mencari Ustaz se } \\
\text { Indonesia yang bisa } \\
\text { menjelaskan dengan cara }\end{array}$ \\
\hline
\end{tabular}




membanggakan sebab dalam dan gaya seperti ini, ya hanya
tuturan tersebut penutur satu yaitu saya ini orangnya,
bermaksud menyampaikan makanya harganya sedikit
rasa bangga terhadap dirinya mahal hahahaha". (TRBng:
$\begin{array}{ll}\text { sendiri. } & 4 \text { ) }\end{array}$

Dalam tuturan membanggakan tersebut terdapat verba pemarkah penanda berupa bentuk kalimat "ya hanya satu yaitu saya". Penanda tindak tutur representatif membanggakan dalam ceramah Ustaz Muhammad Nur Maulana ditandai dengan kalimat "ya hanya satu yaitu saya" yang secara umum sama maknanya dengan kalimat "ya hanya satu yaitu saya".

Tuturan tersebut disampaikan dengan nada ditekan pada kata tertentu dan tuturan disampaikan dengan suara keras, sehingga pendengar dapat mendengarkan tuturan pembicara dan mengingat dengan baik bahwa hanya ada satu ustaz yang dapat menerangkan dengan cara seperti ini. tuturan tersebut disampaikan dengan tersenyum karena tuturan tersebut hanya sebagai penghibur atau pencipta suasana, sehingga para pendengar ceramah yang tadinya merasa bosan atau mengantuk dapat terbangunkan kembali semangatnya untuk mendengarkan ceramah karena dengan mendengarkan tuturan tersebut pendengar tertawa dan terhibur.

Tabel 5 Hasil Temuan Jenis Tindak Tutur

\begin{tabular}{|c|c|c|}
\hline Jenis Tindak Tutur & Konteks & Data Tuturan \\
\hline $\begin{array}{l}\text { e) Tindak tutur } \\
\text { representatif } \\
\text { menyarankan }\end{array}$ & $\begin{array}{l}\text { Tindak tutur representatif } \\
\text { menyarankan isinya tentang } \\
\text { kataqwaan kepada Tuhan. } \\
\text { Tuturan tersebut disampaikan } \\
\text { dengan tegas, nada rendah dan } \\
\text { suara keras, sehingga } \\
\text { pendengar dapat menerima } \\
\text { dan mengingat dengan baik } \\
\text { saran dari penutur. }\end{array}$ & $\begin{array}{l}\text { "Makanha kalau bisa hidup } \\
\text { di dunia ini jadi orang harus } \\
\text { yang baik, harus bs } \\
\text { meninggalkan kenangan yang } \\
\text { baik buat keturunnan anak- } \\
\text { cucu kita. Jika bapak ibu } \\
\text { semua ini jadi orang } \\
\text { baik...ehemm...pasti anak } \\
\text { cucu kita pada bangga, dan } \\
\text { meninggalnya kita itu } \\
\text { didoakan sama anak cucu } \\
\text { kita." (TRSr: 5) }\end{array}$ \\
\hline
\end{tabular}

Tuturan yang disampaikan penutur termasuk dalam tindak tutur representatif menyarankan sebab dalam tuturan tersebut penutur bermaksud menyampaikan sebuah saran atau anjuran kepada mitra tutur atau pendengar agar menjadi orang baik. Dalam tuturan menyarankan tersebut terdapat verba pemarkah penanda "Makanya klo bisa...". Tindak tutur representatif menyarankan dari data yang ditemukan tuturan tersebut disampaikan dengan nada rendah dan suara keras, sehingga pendengar dapat menerima dan mengingat dengan baik saran yang disampaikan oleh penutur. Penutur tidak memaksa kepada pendengar untuk menjalankan saran tersebut. 
Tabel 6 Hasil Temuan Jenis Tindak Tutur

\begin{tabular}{|c|c|c|}
\hline Jenis Tindak Tutur & Konteks & Data Tuturan \\
\hline f) $\begin{array}{l}\text { Tindak tutur } \\
\text { representatif } \\
\text { mengeluh }\end{array}$ & $\begin{array}{l}\text { Tindak tutur representatif } \\
\text { mengeluh berisi } \\
\text { keluhan tentang } \\
\text { manusia. tuturan tersebut } \\
\text { dituturkan dengan suara pelan } \\
\text { dan nada rendah diselingi } \\
\text { dengan humor, sehingga } \\
\text { pendengar dapat memahami } \\
\text { dan mengetahui perbuatan } \\
\text { yang baik dan perbuatan yang } \\
\text { buruk serta merasa senang } \\
\text { dengan tuturan yang } \\
\text { disampaikan oleh Ustaz } \\
\text { Muhammad Nur Maulana. }\end{array}$ & $\begin{array}{l}\text { "Ada juga yang pulangsholat } \\
\text { Jumat pakai baju kokoyang } \\
\text { saku kantungnya ada dua, } \\
\text { sebelah kanan isinya uang } \\
\text { seratus ribu dan sebelah kiri } \\
\text { isinya dua ribu, yang } \\
\text { rencananya abis sholat Jumat } \\
\text { mau mampir ke warung kopi. } \\
\text { Pas di masjid ada kotak amal } \\
\text { yang lewat pas lagi ngantuk } \\
\text { dan ternyata salah masukin. } \\
\text { Habis pulang dari sholat } \\
\text { Jumat minum kopi sampe } \\
\text { habis, dan niat mau buat } \\
\text { bayari, buat amal aja pelit } \\
\text { astagfirullah halazim. } \\
\text { Ini karena apa coba? } \\
\text { Keliru yang seratus ribu } \\
\text { masuk kotak amal nyeselnya } \\
\text { sampe berhari-hari enggak } \\
\text { lupa-lupa, Allah Yakarim". } \\
\text { (TRKh: 6) }\end{array}$ \\
\hline
\end{tabular}

Tuturan yang disampaikan oleh penutur termasuk tindak tutur representatif mengeluh sebab dalam tuturan tersebut penutur bermaksud menyampaikan kekecewaannya terhadap sikap yang dimiliki oleh orang yang diceritakan tersebut. Dalam tuturan mengeluh tersebut terdapat pemarkah penanda mengeluh berupa bentuk frase "Allah Yakarim". Penyebutan asma Allah tersebut dimaksudkan sebagi ungkapkan kecewa. Tuturan disampaikan dengan suara pelan, nada rendah serta diselingi dengan humor, dan ekspresi kecewa, sehingga pendengar dapat memahami tuturan yang disampaikan oleh pembicara. Tuturan tersebut disampaikan dengan cara seperti itu untuk mengungkapkan rasa kekecewaan penutur. Tuturan tersebut disampaikan kepada pendengar tujuannya agar pendengar tidak berbuat hal yang sama seperti contoh yang diceritakan oleh penutur. Dengan ditunjukkannya contoh tuturan tersebut pendengar dapat membedakan perbuatan yang baik dan perbuatan buruk.

Tabel 7 Hasil Temuan Jenis Tindak Tutur

\begin{tabular}{lll}
\hline Jenis Tindak Tutur & Konteks & Data Tuturan
\end{tabular}

g) Tindak tutur Tindak tutur representatif "Saya lihat banyak wajahrepresentatif melaporkan berisi tentang wajah yang sumringah cerah melaporkan kewajiban setiap manusia, nan indah, mudah-mudahan yang dituturkan dengan nada bapak ibu wajah seperti inilah 


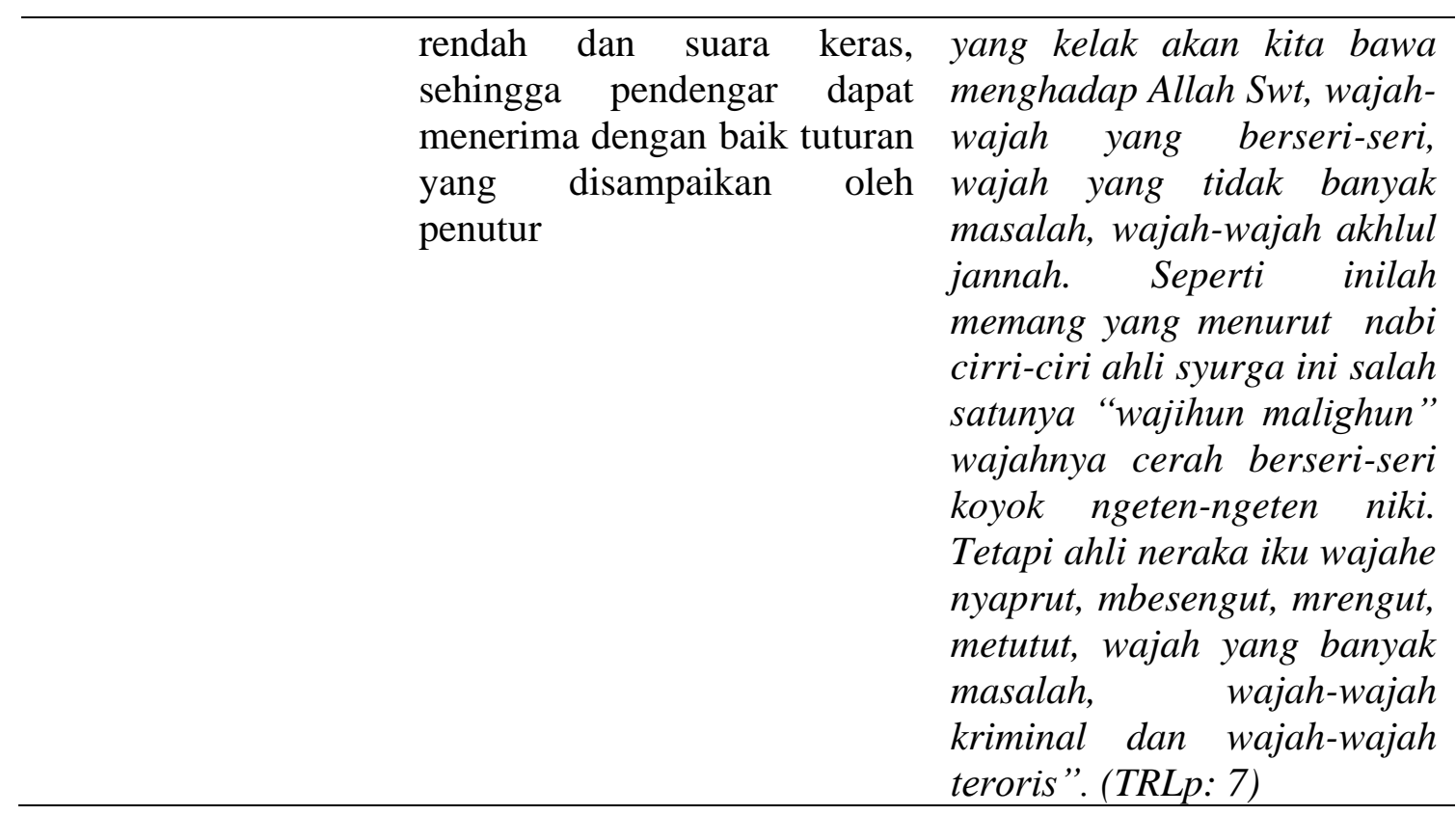

Tuturan yang disampaikan oleh penutur termasuk tindak tutur representatif melaporkan sebab penutur bermaksud memberitahukan secara langsung apa yang dilihatnya kepada mitra tutur atau pendengar. Dalam tuturan melaporkan tersebut terdapat verba pemarkah penanda melaporkan berupa frase "saya melihat.

Tuturan tersebut disampaikan dengan nada pelan, dan tuturan disampaikan dengan suara keras, sehingga pendengar dapat menyimak dan menerima dengan baik tuturan penutur bahwa setiap manusia harus belajar untuk menjadi ahli surga.

Tabel 8 Hasil Temuan Jenis Tindak Tutur

\begin{tabular}{lll}
\hline Jenis Tindak Tutur & Konteks & Data Tuturan
\end{tabular}

h) Tindak tutur representatif menunjukkan

Tindak tutur representatif "Allah SWT member lambang
menunjukkan berisi tentang kalau manusia itu memang
kedudukan manusia, ketidak tidakpunyaapa-apa. Manusia
berdayaan manusia, dan datang lahir ke dunia brojol
akhlak manusia, yang dengan rupa bayi telanjang
dituturkan dengan jelas dan bulat!tidak membawa apa-
tegas, dengan nada ditekan apa, tidak punya modal apa-
pada kata tertentu, serta apa, semua orang lahirnya
dituturkan dengan suara keras telanjang, yang sekarang
dan diselingi dengan humor sudah menjadi pejabat, itu
sehingga pendengar dapat jugalahirnya telanjang, yang
memahami, menangkap sekarang jadi guru, juga dulu
dengan baik, dan merasa waktu lahir telanjang, dan
senang dengan apa yang yang sekarang jadi bupati
disampaikan oleh penutur.
juga dulu lahirnya telanjang,
dan bahkan yang sekarang
jadi Kyaiatau Ustazjugadulu


lahirnya telanjang.”. (TRTj:

8)

Tuturan yang disampaikan oleh penutur termasuk dalam tindak tutur representatif menunjukkan sebab dalam tuturan tersebut penutur bermaksud menunjukkan atau memperlihatkan kepada pendengar atau mitra tutur bahwa manusia itu dulu lahir di dunia tidak punya apa-apa dan tidak membawa apa-apa. Dalam tuturan menunjukkan tersebut terdapat verba pemarkah penanda menunjukkan berupa bentuk kata "itu".

Tuturan tersebut disampaikan dengan tegas, nada ditekan pada kata tertentu, tuturan disampaikan dengan suara keras. Tuturan tersebut disampaikan dengan cara seperti itu untuk memperjelas tuturan, sehingga pendengar dapat mengetahui dan memahami dengan baik tuturan yang disampaikan penutur bahwa semua manusia di dunia itu sama tidak ada bedanya dihadapan Allah.

2. Modus tindak tutur representatif yang digunakan dalam ceramah Ustaz Muhammad Nur Maulana adalah:

Tabel 1 Hasil Temuan Modus Tindak Tutur

\begin{tabular}{ll}
\hline Modus Tindak Tutur & \multicolumn{2}{c}{ Konteks } & Data Tuturan \\
\hline a) Modus interogatif & Modus interogatif berisi “Bapak ibu sekalian yang \\
& tentang hak hidup manusia, mulia dan kemegahan di \\
& amal kebaikan, dan akhlak dunia ini adalah hartanya \\
& manusia, yang dituturkan orang yang tidakpunya harta \\
& dengan jelas, tegas, nada karena apa?kita semua di \\
& ditekan pada kata tertentu, dunia ini ternyata sementara, \\
& dituturkan dengan suara keras semua barang yang ada \\
& dan diselingi dengan humor, didunia itu hanya untuk \\
& sehingga pendengar dapat bergantian". (M Int: 1) \\
& memahami, mengingat \\
& dengan baik dan merasa \\
& senang dengan tuturan yang \\
& disampaikan oleh penutur.
\end{tabular}

Tuturan tersebut mengungkapkan pertanyaan kepada pendengar atau mitra tutur kenapa dunia ini disebut hartanya orang yang tidak memiliki harta. Tuturan tersebut merupakan tuturan yang menggunakan modus interogatif sebab disertai penanda "... mulia dan kemegahan di dunia ini adalah hartanya orang yang tidak punya harta karena apa?". Tuturan tersebut merupakan penggambaran bahwa semua manusia di dunia memiliki hak yang sama, baik berupa hak untuk belajar, hak untuk mendapatkan kedudukan, maupun hak untuk mencintai seseorang. 
Tabel 2 Hasil Temuan Modus Tindak Tutur

\begin{tabular}{lll}
\hline Modus Tindak Tutur & Konteks & Data Tuturan
\end{tabular}

b) Modus imperatif Modus imperatif berisi "Jika disini ada lelaki yang tentang larangan untuk mau nikahin janda membatasi hak hidup manusia temannya, dengan dalih dan perintah untuk menjadi meneruskan perjuangan orang baik. Tuturan tersebut sang teman. Cuma pesan disampaikan dengan jelas dan saya dirawat yang bener ya suara keras, sehingga pak ya, nanti jangan punya pendengar dapat memahami, fikiran eh...ini kan titipan menerima, dan mengingat orang. Jangan sampe begitu dengan baik tuturan yang ya pak yah. Karena disampaikan penutur. maksudnya kan begini pak, ibu ini kan istri bapak sendiri, yah harusbapak sayang bener-bener tulus dan ikhlas. Karenananti jika bapak sendiri yang meninggal itu gentian, istribapak bakal sayang dan cinta sama orang lain”. (M Imp: 2)

Tuturan tersebut mengungkapkan larangan atau tegahan kepada pendengar khususnya pada bapak-bapak yang akan menikah lagi untuk tidak memiliki fikiran bahwa wanita yang akan dinikahi berarti wanita sisanya orang. Tuturan tersebut merupakan tuturan yang menggunakan modus imperatif sebab disertai penanda "...jangan sampai begitu". Tuturan tersebut merupakan penggambaran bahwa semua manusia di dunia memiliki hak yang sama.

Tabel 3 Hasil Temuan Modus Tindak Tutur

\begin{tabular}{lll}
\hline Modus Tindak Tutur & \multicolumn{1}{c}{ Konteks } & Data Tuturan \\
\hline c) Modus desideratif & Modus desideratif berisi “Anda jika ingin tentram \\
& tentang akhlak buruk manusia hidupnya, bahagia sakinah \\
& dan kewajiban manusia, yang & mawadah rumah tanggana \\
& dituturkan dengan tegas, nada itu tugasnya hanya satu, \\
& ditekan ditekan pada kata manfaatkan”. (M Des: 3) \\
& tertentu, dituturkan dengan \\
& suara keras, sehingga \\
& pendengar dapat memahami \\
& dan mengingat dengan baik \\
& tuturan yang disampaikan \\
& penutur.
\end{tabular}


Tuturan tersebut penutur menyatakan kepada pendengar apabila pendengar ingin hidupnya tentram, sakinah mawadah rumah tangganya tugasnya hanya satu, manfaatkan. Tuturan tersebut merupakan tuturan yang menggunakan modus desideratif sebab disertai dengan penanda kata "Ingin". Tuturan tersebut merupakan penggambaran tentang keinginan semua manusia untuk mendapatkan kedamaian dan kebahagiaan.

Tabel 4 Hasil Temuan Modus Tindak Tutur

\begin{tabular}{lll}
\hline Modus Tindak Tutur & \multicolumn{2}{c}{ Konteks } \\
& \multicolumn{2}{c}{ Tutaran } \\
\hline d) Modus obligatif & Modus obligatif berisi "Semua orang yang \\
& tentang ketidak berdayaan meninggal harusnya kalau \\
& manusia. Tuturan tersebut cara nalar meninggal itu \\
& disampaikan dengan tegas, ngempet dua tangannya \\
& nada ditekan pada kata ngepal tapi kenyataannya \\
& tertentu, dituturkan dengan tidak, emang ada mayat \\
& suara keras, sehingga mengingal tanganyangepal". \\
& pendengar mengetahui dan (M Obl: 4) \\
& memahami dengan baik \\
& tuturan yang disampaikan \\
& oleh penutur.
\end{tabular}

Tuturan tersebut mengungkapkan bahwa orang kalau sudah meninggal seharusnya tangannya menggenggam karena menahan sakit tetapi pada kenyataannya tidak ada orang meninggal tangannya menggenggam. Tuturan tersebut merupakan penggambaran tentang kekuasaan manusia tidak lebih besar dibandingkan dengan kekuasaan Tuhan karena segala sesuatu yang dimiliki oleh manusia kelak akan kembali lagi pada Tuhan.

Tabel 5 Hasil Temuan Modus Tindak Tutur

\begin{tabular}{lll}
\hline Modus Tindak Tutur & Konteks & Data Tuturan
\end{tabular}

e) Modus optatif Modus optatif berisi tentang "Saya lihat banyak wajahkewajiban manusia, yang wajah yang sumringah dituturkan dengan nada pelan, cerah nan indah, mudahdan disampaikan dengan suara mudahan bapak ibu wajah keras, sehingga pendengar seperti inilah yang kelak menerima dengan baik tuturan akan kita bawa yang disampaikan oleh menghadap Allah Swt, penutur. wajah-wajah yang berseri-seri, wajah yang tidak banyak masalah, wajah-wajah akhlul jannah. Seperti inilah memang yang menurut nabi cirri-ciri ahli syurga ini salah satunya "wajihun 


\begin{tabular}{l}
\hline malighun" wajahnya \\
cerah berseri-seri koyok \\
ngeten-ngeten niki. Tetapi \\
ahli neraka iku wajahe \\
nyaprut, mbesengut, \\
mrengut, metutut, wajah \\
yang banyak masalah, \\
wajah-wajah kriminal dan \\
wajah-wajah teroris". (M \\
Opt: 5) \\
\hline
\end{tabular}

Tuturan tersebut mengungkapkan harapan dan keinginan penutur kepada pendengar atau mitra tutur nantinya apabila menghadap Tuhan wajah yang berseri-seri, wajah yang tidak banyak masalah, wajah yang akhlul jannah yang akan di bawa. Tuturan tersebut merupakan tuturan yang menggunakan modus optatif sebab disertai dengan penanda "mudah-mudahan". Tuturan tersebut merupakan penggambaran tentang kehidupan manusia setelah hidup di dunia.

\section{SIMPULAN}

Berdasarkan hasil dan pembahasan yang telah diuraikan, maka dapat diambil kesimpulan bahwa dalam ceramah Ustaz Muhammad Nur Maulana menggunakan jenis tindak tutur representatif. Selain itu, Ustaz Muhammad Nur Maulana juga menggunakan jenis modus yang menarik dan representatif, seperti modus introgatif, imperatif, desideratif, dan optatif yang berisi tentang hubungan manusia dengan Tuhan dan hubungan manusia dengan manusia, dituturkan dengan serius dan dipadukan dengan gurauan, sehingga pendengar paham, merasa senang dan puas mendengarkan ceramah yang disampaikan oleh Ustaz Muhammad Nur Maulana. Penyampaian materi ceramah dengan cara seperti itu membuat penceramah menempati tempat tersendiri di hati masyarakat pendengarnya.

\section{DAFTAR PUSTAKA}

Chaer, A. (2010). Linguistik umum. Jakarta: Rineka Cipta.

Moleong, L. J. (1996). Metode penelitian kualitatif. Bandung: Rosdakarya

Strauss, A. \& Corbin, J. (2007). Dasar-dasar penelitian kualitatif. Yogyakarta: Pustaka Pelajar.

Sukamadinata, N. S. (2010). Metode penelitian pendidikan. Bandung: PT. Remaja Rosdakarya Offset.

Tarigan, H. G. (1990). Pengajaran pragmatik. Bandung: Angkasa.

www.youtube.com. (2018). Islam itu indah. Diambil dari: https://www.youtube.com/ results?search_query=islam+itu+indah+trans+tv+tadi+pagi+tema+sabar\%2C+ik hlas\%2C+modal+untuk+Istiqomah. 